\title{
Mythological Names and dróttkvætt Formulae III: From Metric-Structural Type to Compositional System
}

Frog*

\begin{abstract}
This article explores patterns of language use in oral poetry within a variety of semantic formula. Such a formula may vary its surface texture in relation to phonic demands of the metrical environment in which it is realised. This is the third part of a four-part series based on metrically entangled kennings in Old Norse dróttkveett poetry as primary material. Old Norse kennings present a semantic formula of a particular type which is valuable as an example owing to the extremes of textural variation that it enables. The study concentrates on two-element kennings meaning 'battle. The first part in this series introduced the approach to kennings as semantic formulae and illustrated their formulaicity through evidence of the preferred lexical choices with which they were realised. The second part presented a case study illustrating that preferred word choices could extend beyond the kenning to additional elements in the line like rhyme words. The third case study presented here concentrates on the potential for a formula of this type to develop a general preference for elements of the kenning to come from one semantic category rather than another without such choices being metrically motivated per se.
\end{abstract}

Keywords: oral poetry, variation, formula, skaldic poetry, dróttkvoett, kenning

The present case study is concerned with a phenomenon of variation in oral poetry. The approach focuses on oral poetry as language practice. The study looks at a type of semantic formula in Old Norse poetry that is metrically entangled with the dróttkvoett meter. Emphasis is on socially conditioned preferences in word choice for realising that formula. The semantic formula addressed here has been identified and analysed through the circumlocutions called kennings. The analysis is built as a survey of kennings with the same referent ('battle') occurring in equivalent metrical positions in a dróttkvoett line - i.e. kennings of the same metric-structural type. The dataset of 40

* Author's address: Frog, Folklore Studies / Department of Philosophy, History, Culture and Art Studies, University of Helsinki, P.O. Box 59 (Unioninkatu 38 A), 00014 University of Helsinki, Finland. E-mail: mr.frog@helsinki.fi. 
examples was assessed to consider whether distinctive patterns of language use indicative of formulaicity could be observed.

This is the third of a series of three case studies in a four-part discussion; it will be later followed by a discussion of the relationships between the studies and their broader implications. Part I (MNDF I) presented the register-based approach to oral poetry employed here as well as the framework for approaching semantic formulae. This was illustrated through a case study of metric-structural type 12(p)XYy battle-kennings. This study showed that personal names associated with mythology could vary with other nouns in a battle-kenning as a formula in these metrical positions. Moreover, it revealed the crystallisation (i.e. obtaining a relative degree of fixity) of lexical material in the formation of battle-kennings of a metric-structural type. Particular attention was given to the value of these personal names for meeting metrical demands, especially rhyme. Part II (MNDF II) focused on the metrical entanglement of the lexicon within a basic (metric-structural) type, reviewing 80 examples of type 1(p)YyXx battlekennings. Attention focused on the index or link of association of particular base-words when used in this metric-structural type to a semantic category of determinant completing the kenning. It also gave further attention to the indexical links formed with other material completing the line. This study showed that personal names as a broad category could become metrically entangled in the realisation of particular battle-kennings as a preferred choice to accompany certain base-words and not others. Names from mythology appeared among these as an integrated resource in composition. The present case study treats basic type YyX456 battle-kennings in order to consider the potential for the metrically entangled formula itself to index a semantic category of determinant. In other words, it sets out to consider whether the use of a battle-kenning in certain metrical positions is not only formulaic, but that the formula may have a tendency to use a mythological name as a determinant. It may be stated at the outset that evidence from earlier studies anticipate this finding. The pilot study preceding the present series of case studies already revealed metrically entangled kennings in certain metrical positions through evidence of preferred word choices (Frog 2015a). The preceding case studies in this series have shown that certain choices for one word in such a formula may not only index choices for an accompanying word (MNDF I) but also a whole category of semantically equivalent words (MNDF II). It is only a short step to consider that the preference of drawing on a particular semantic category may occur for the whole metrically entangled kenning. The purpose here is to explore that possibility. To aid the accessibility of this article for readers who may not be familiar with the first parts of this series, the case study will be preceded by a short review of the background of the study and the framework used here. 


\section{Background and Terms}

This series of case studies is developed on the basis of a pilot study that set out to test the hypothesis that kennings could become metrically entangled semantic formulae (Frog 2015a). The pilot study surveyed 340 kennings in dróttkvott-meter poetry that had the referent 'battle'. These kennings were analysed in their metrical contexts in order to assess whether any of them exhibited evidence of formulaicity. The material was viewed through a register-based approach to oral poetry as language practice. This approach links with current understandings of Oral-Formulaic Theory, which has developed considerably in roughly the half-century since the publication of Albert Lord's Singer of Tales (1960). Register is a term to describe a variety of language or other semiotic behaviour linked to certain types of communicative situations (e.g. Agha 2007; cf. also Halliday 1978) and is well suited to approaching a tradition of oral poetry (e.g. Foley 1995). This term is an analytical tool, the sensitivity and scope of which can be calibrated to the research object (Frog $2015 b)$. The register or sub-register of dróttkvoett describes especially those expressive resources conventional to the dróttkvott meter and associated with its particular metrical demands. A formula, whether simple or complex, is a meaning-bearing integer of the linguistic register that develops an exclusive entry in the mental lexicon of competent users (e.g. Wray 2009: 28-34; Foley \& Ramey 2012: 80). Key indicators of formulaicity are therefore evidence that the potential formula is somehow formally and or semantically distinctive within the register.

Dróttkvatt is essentially a syllabic meter (with rule-governed flexibility) of six-position lines composed in couplets, with two couplets forming a halfstanza. Rules of syntax allowed a remarkable scrambling of language through a half-stanza unit, and two (rarely more) clauses or independent statements could be interwoven across those four lines. The main conventional formal constraints of the meter are rhyme, alliteration and syllable weight. Two lexically stressed syllables in odd lines should alliterate with the first stressed syllable in the following even line of a couplet. Rhyme was more variable in practice, but normally the penultimate syllable (but not the following inflectional ending) of each line should rhyme with a preceding syllable; in odd lines, this should be skothending rhyme, not including the vowel (e.g. 1a.v below: geira veðrs til gódrar); in even lines, this should be aðalhending rhyme, including the vowel (e.g. 1a.iii below: Hogna veðr i gognum). The syllabic quality described metaphorically as 'weight' was also significant, although the precise metrical rules surrounding it remain debated. Syllabic weight has only limited relevance to the present discussion and need not be introduced 
in detail: it is sufficient to observe that certain stressed syllables were 'heavy' and this quality affected the metrical positions in which words were used. ${ }^{1}$

A kenning is a rhetorical figure that forms a Noun Phrase (NP). This rhetorical figure is formed of a noun called a base-word $\left(\mathrm{NP}_{1}\right)$ complemented by a second noun called a determinant $\left(\mathrm{NP}_{2}\right)$ in the genitive case or forming a compound, and these together signify a third, nominal referent (thus: $\mathrm{NP}_{2}-\mathrm{GEN}$ $\mathrm{NP}_{1}$ or $\mathrm{NP}_{2}-\mathrm{NP}_{1}=\mathrm{NP}_{3}$ when $\mathrm{NP}_{3} \neq \mathrm{NP}_{1}$ or $\mathrm{NP}_{2}$ ). For example, the base-word $v e \partial r=$ 'weather; wind' can be complemented by the determinant geirr = 'spear' to form a battle-kenning in the following ways: veðr geirs = 'weather of the spear', veðr geira = 'weather of spears' or geirveðr = 'spear-weather'. In most registers (poetic or otherwise), kennings are for the most part crystallised formulaic expressions or have become wholly lexicalised, fossilised and idiomatic. Kennings in skaldic poetry are exceptional because they functioned generatively: the register was characterised by a rich lexicon of semantically equivalent terms called heiti (sg. also heiti) which could be interchangeable in realising a particular kenning as a semantic unit according to "paradigmatic substitution" (Clunies Ross et al. 2012: lxxi). In the above example, veðr is a weather-heiti interchangeable with él = 'squall', $d r i f a=$ 'snowstorm', $h r e g g=$ 'rainstorm', hrí = 'storm', regn = 'rain', skúr = 'shower', etc. At the same time, geirr can vary with other spear-heiti, and also within a broader equivalence class with other weapon-heiti, and still more generally with heiti for implements of battle. This potential for variation is expanded by the potential for especially the NP of the determinant to be realised through another kenning, and the determinant NP of that kenning to be realised through yet another kenning, and so on. A two-element kenning can be called a basic kenning or a simple kenning. This type of variation turns a basic kenning into a complex kenning (i.e. $\left.\left[\mathrm{NP}_{n}-\mathrm{GEN} \mathrm{NP}_{3}\right]-\mathrm{GEN} \mathrm{NP}_{2}\right]-\mathrm{GEN} \mathrm{NP}_{1}=\mathrm{NP}_{4}$, etc.).

In the pilot study, the metrical positions for each element of each battlekenning were 'mapped' within a line or across lines of a half-stanza. Mapping is done by representing each six-position line as a numerical sequence 123456. Each position filled by a kenning's base-word is replaced with an ' $\mathrm{X}$ ' and each filled by the determinant with a ' $Y$ ' (' $Z$ ' was used to represent the determinant in the determinant kenning) and 'p' replaced a preposition (placed in parentheses if optional). Uppercase characters represent the stressed onset syllable and lowercase characters represent unstressed positions. Thus, the line geira veðrs til góðrar = 'weather of spears...' (1a.v) can be mapped geira-veðrs-p56,

1 On the dróttkveett meter, syntax and structuring of stanzas, see further Kuhn 1983: 33-214; Árnason 1991: 81-148; Gade 1995: 1-72; on complexity in skaldic composition, see Wills 2009. 
Yy-veðr-p56, YyX(p)56, YyX456, etc. Mapping the kennings in this way distinguished them according to the metric-structural types described by these codes. A kennings of only two elements presented a 'basic type' while a kenning of three or more elements presented a 'complex type' (although only two-element kennings are surveyed in the case-study below). ${ }^{2}$

The working hypothesis of the pilot study was that kennings could develop conventional use "under the same metrical conditions" (Parry 1928: 16). Albert Lord (1960: 48-53) had observed that one lexical element of a formula might vary between poetic synonyms. It was hypothesised that, in dróttkvott poetry, kenning use could develop corresponding formulae able to "express a particular essential idea" (Parry 1928: 16) in particular metrical positions (i.e. a metric-structural type) but the heiti of both kenning elements could vary. Dominant models for approaching kennings have focused on the semantic categories of constituent heiti and the relationship of these heiti to one another (e.g. Meissner 1921; Marold 1983: 24-36). Accordingly, it was hypothesised that both elements of a kenning formula targeted by the study would vary within their respective equivalence classes of heiti. Surprisingly, the vast majority of kennings in the pilot study appeared in quite a limited number of basic metric-structural types (with variations) with indications of formulaicity. Contrary to expectation, however, variation between heiti in examples of the apparent formulae did not remain within individual semantic equivalence classes. Instead, syllabic structure seemed to be a primary determinant on which possible heiti were used. A survey of the heiti used as base-words and 'basic' determinants ${ }^{3}$ revealed that these fell into groups by relative frequency and, for example, the high-frequency heiti of the corpus appeared to be characterised by their ability to meet different patterns of alliteration irrespective of semantic class. This led to an alternative model of viewing metrically entangled kennings as formulae within which lexical variation was in terms of functional rather than semantic equivalence for realising the formula as a unit meaning 'battle' (Frog 2015a; MNDF I: 109-117; MNDF II: 45-47). For example, weather-heiti such as veðr can form a battle-kenning with heiti for implements of battle like geirr as in (1a.v) below, or with heiti for agents of battle like the valkyrie-name Gondul (veðr Gondlar as in MNDF II, ex. 3b.vi). In practice, variation occurs between geirr and Gondul within a formula of this

2 Descriptions of complex types accounted for all elements in complex kennings, but kennings of three elements or more were observed to generally reflect two or more basic types in combination that could be viewed as systematic expansions varying a basic type.

3 On basic determinants as a category for analysis of data including both basic and complex kennings, see further Frog 2015a. 
type because these heiti could be functionally equivalent for realising a formula meaning 'battle' in the appropriate metrical positions irrespective of their individual semantics. Similarly, the base-word ping = 'assembly' may belong to a different semantic equivalence class than $v e \partial r$, but these are nevertheless functionally equivalent as base-words in producing the semantic unit 'battle', as in ping Gondlar in (1b.ii) below or ping geira in MNDF II (ex.5b.v). Any combination of these base-words and determinants will realise the same integer 'battle': they are functionally equivalent in forming the kenning and metrically equivalent for the particular metrically entangled formula (cf. 1a-b).

\section{Basic Type YyX456 Battle-Kennings in Overview}

In the pilot study, 22 of the 340 battle-kennings analysed were basic type YyX(p)56 battle-kennings (including variations). Of these, 9 or approximately $41 \%$ had a personal name of a mythic agent as a determinant. The prominence of personal names was quite striking within the context of that data. This basic type was therefore selected to explore the possibility that mythic agents of battle could become a preferred category of determinant in a metrically entangled kenning as a semantic formula (observable in kennings of a particular metric-structural type). Searching the corpus for this particular basic type approximately doubled the size of the dataset with a total of 40 examples. As in the preceding studies of other basic types, adjectives are not counted as variations on the type. ${ }^{4}$ In general, variations of this basic type that expanded it into a complex kenning were only infrequently observed (i.e. [ $\mathrm{NP}_{3}$-GEN $\mathrm{NP}_{2}$ ]-GEN NP${ }_{1}=\mathrm{NP}_{4}$ ). These variations are not counted in the data discussed here. Of the 40 examples, 17 or $42.5 \%$ have a proper name as a determinant, of which 15 or $37.5 \%$ are proper names for mythic agents of battle. This proportion remained generally consistent with the proportion observed in the pilot study, making it less likely that the pattern is an accident of sampling.

Basic type $\mathrm{YyX}(\mathrm{p}) 56$ battle-kennings are found in both odd and even lines. The formal structure of course places constraints on the number of syllables of both the base-word and the determinant. Syllabic weight also appears to be

4 These were not found to metrically or semantically impact the formulaic unit; cf. examples in Eskál Vell $10^{\mathrm{I}} .7-8$, pjóðA Sex $2^{\mathrm{II}} .5-6$, Sigv Víkv $2^{\mathrm{I}} .1,3$, Sigv Frag $1^{\mathrm{III}} .3-4$ and Anon Gyð $5^{\mathrm{VII}} .3-4$. Citations are by sigla and stanza numbering of the Skaldic Database. Citations are with reference to the published editions of the associated Skaldic Poetry of the Scandinavian Middle Ages (SPSMA) edition where these were available and with reference to Finnur Jónsson's critical edition (1967) where they were not. 
entangled with kennings of this type: the determinant always exhibits a heavy stressed syllable in its two-syllable genitive inflection whereas the base-word invariably appears as a heavy monosyllable whatever its inflection. The formula is also always followed by a preposition or other light particle of speech. As stress is regular in position 5 (also a heavy syllable), use of this formula produces a clear trochaic rhythm in the line. In even lines, the determinant is metrically required to carry alliteration. In odd lines, the determinant also invariably carries alliteration, and always with the penultimate syllable; never with the base-word. This metric-structural type of kenning therefore appears entangled with the distribution of alliteration in the line beyond the kenning (forming line-type A2; cf. Gade 1995: 18). Unlike basic types addressed in Parts I and II of this series, line-positions 5-6 stand outside of the positions of kenning elements in this type. Line-position 5 is required to carry rhyme for the line, which is most often also carried by the base-word here but it is carried by the determinant roughly a quarter of the time. ${ }^{5}$ Rhyme does not appear entangled in this formula to the same degree as alliteration.

YyX $(p) 56$ battle-kennings not infrequently appear as determinants in complex kennings (genitive inflections are indicated by '.GEN' in the translations of examples). The kenning Gondlar ping = 'assembly of Gondul (valkyrie)' (1b.ii) is the determinant for another common battle-kenning determinant gnýr = 'roar' in the four-element warrior-kenning Gondlar pings gný-Próttr (Hskv Uttdr 7"II $7-8)$ = 'Próttr (Odin) of the roar of the assembly of Gondul.' Participation in complex kennings appears to be a normal function of many basic-type kenning formulae and did not warrant distinction in analysis (Frog 2015a; cf. however Sverdlov 2015). This use of a formulaic kenning only requires morphological variation for a genitive inflection of the determinant. Morphological variation is subject to metrical constraints as in other formulaic metric-structural types, which in this case is relevant to the formation of extended kennings. The requirement of a heavy monosyllable base-word has

\footnotetext{
5 In 9 of the 40 examples (1a.i-iii, 1b.iii-iv, 2a.ii, 2a.iv, 3b.i, 4b.ii; although see also below), noting that 3a.i lacks rhyme and a lacuna follows 4a.iv (although the metric-structural type of the kenning in the line can be considered unambiguous).

6 Cf. e.g. odda pings hyr-Próttr (Anon Pl 48 ${ }^{\mathrm{VII}} .2-3$ ) in which hyr = 'flame' forms a swordkenning: $\mathrm{NP}_{2}$-próttr is the same metric-structural type in both examples and it is also in a line adjacent to the Yy-pings-(p)56 battle-kenning, yet gný-Próttr follows the battle-kenning and carries alliteration in the couplet while hyr-Próttr precedes the battle-kenning in the preceding couplet.
} 
consequences here such as, for example, gnýr only being metrically viable in the nominative or genitive singular ( $g n y$-r or gný-s but not $g n y ́-\varnothing){ }^{7}$

The use of $\mathrm{YyX}(\mathrm{p}) 56$ kennings as determinants is of interest from the perspective of the rhythm and metrics of these lines. It is rhythmically unsurprising that metrical position 4 in these lines is invariably filled by a light particle of speech. This fact becomes interesting because, metrically, this use of a light particle of speech does not seem like it should be significantly different than an inflectional ending on the preceding noun. However, YyX(p)56 battle-kennings do not exhibit a variation of extending the kenning into position 4 by adding an inflectional ending to the base-word (i.e. YyX(p)56 $\rightarrow$ YyXx56) and no battle-kennings of type YyXx56 were found in the test corpus of the pilot study. ${ }^{8}$ It seems probable that the absence of type YyXx56 battlekennings somehow reflects conventions of the rhythms of the meter. ${ }^{9}$ The monosyllabic base-words are always heavy in this formula. When searching the Skaldic Database for examples of this basic type, it was also observed that battle-kenning base-words with a heavy monosyllable stem and inflected with a genitive singular ending $-s$ seem almost never to occur outside of this position (e.g. mót = 'meeting', gen. móts; ping, gen. pings; veðr, gen. veðrs) unless they form part of a compound. The use of this morphological form in position 3 but not elsewhere further suggests that this formula is somehow interfaced with a relationship between syllabic weight and rhythm in the meter.

Unlike examples of basic types in Parts I and II, lexically identical kennings of basic type $\mathrm{YyX}(\mathrm{p}) 56$ occur in both odd and even lines. This appears related to the fact that neither the base-word nor the determinant fills the rhyme-determining position 5. However, the structure of the line nevertheless requires one of the elements of the kenning to carry the rhyme (if rhyme is not absent) and recurrent rhyme-collocations in the data may be considered evidence of conventional resources in this area as well (see below). The preceding case studies in this series organised the presentation of examples according

7 This was especially clear in basic type 12(p)XYy battle-kennings, where the base-word had to be a light monosyllable, which had the opposite consequence of effectively limiting use to -Ø inflections.

8 Mention of basic type YyXx56 in footnote 13 of MNDF II (p. 48) is a labelling error for complex type ZYXx56 in which ZY is a compound.

9 Two examples of type XxYy56 battle-kennings were found in test corpus (Epver Lv $1^{\mathrm{I}} .8$ and GPorg Lv $1^{\mathrm{V}} .7$ ), but their word order can be considered 'inverted' and there is no reason to believe that these were formulaic as battle-kennings. On the potential for conventional, metrically entangled formulae to reveal qualitatively better information in the metrical analysis of oral poetry, see Frog 2014a. 
to their use in odd and even lines, but examples of identical kennings in both odd and even lines makes such a division seem inappropriate here, especially as the set of 40 examples does not present more than five examples with any single base-word or determinant. The present data is therefore grouped by base-word in order of the number of examples.

Owing to the limited number of examples for any one base-word in basic type $\mathrm{YyX}(\mathrm{p}) 56$ battle-kennings, it is not possible to draw unambiguous conclusions regarding how that base-word is used. The use of names with any one base-word also does not seem astounding. Although examples are grouped by base-word, the methodological focus in this survey is the observance of a cumulative trend or tendency. The survey of the pilot study provides a frame of reference for the use of proper names here. In the pilot study, 41 or ca. $12 \%$ of the 340 battle-kennings (including complex kennings) employed proper names in/as determinants. Part I of this study drew attention to the crystallisation of verbal formulae incorporating names (MNDF I: 124-125) and Part II highlighted that certain base-words within a formulaic metric-structural type may show preferred use of personal names as determinants (MNDF II: 62-64). Those phenomena were already to some degree observable in the pilot study, where it was clear that proper-name determinants were more frequent in at least some basic types than in others (which led to the present series of case studies). If this is taken into account and a rough and general calibrated average of uses of proper-name determinants is estimated at ca. 1 in 10 examples (cf. MNDF II: 25), proper names in 17 of the 40 examples here and mythic agents of battle in 15 of 40 (i.e. 3 in 8) examples looks remarkable.

\section{Base-Words in Five Examples}

The base-words veðr = 'weather' and ping = 'assembly' are each found in 5 examples. These were both found to be high-frequency base-words in the pilot study and the number of examples in which they are found here is not necessarily surprising in itself. ${ }^{10}$ Within each set of 5, one determinant is also found twice: these

10 Cf. the appearance of ping as the base-word in ca. $9 \%$ of the 340 examples in the sample corpus and $v e ð r$ in ca. 6.5\%. Base-words were considered high frequency when found in more than $5 \%$ of the examples, the highest-frequency base-word being él = 'squall' in 33 examples or ca. $10 \%$. In the present case study, 5 of 40 examples is $12.5 \%$. This may look a bit high at first glance, but the calculations made in the pilot study included all base-words, whereas here only base-words that are a heavy monosyllable are metrically viable. If only the base-words in the pilot study that are metrically viable here were tallied, their relative frequency would rise. 
account for 4 of the 9 examples in which the determinant carries the rhyme in the line and they produce phonetically and verbally similar lines (1a.i-ii, 1b.iii-iv).

(1a) Yy-veðr(s)-(p)56

\begin{tabular}{|l|l|l|}
\hline Laufa veðr at lífi & 'weather of Laufi (sword)... & Eskál Vell $10^{\mathrm{I}} .7$ \\
\hline Laufa veðrs, peirs leyfa & 'weather.GEN of Laufi (sword)...' & Porhv Lv $2^{\mathrm{V}} .7$ \\
\hline Hogna veðr í gognum & 'weather of Hogni (hero)... & Arn Magndr $13^{\mathrm{II}} .6$ \\
\hline Hamðis veðr' ${ }^{11}-$ á heiðar & 'weather of Hamðir (hero)...' & GOdds Lv $2^{\mathrm{IV}} .3$ \\
\hline geira veðrs til góðrar & 'weather.GEN of spears...' & GSvert Hrafndr $5^{\mathrm{IV}} .7$ \\
\hline
\end{tabular}

(1b) Yy-ping(s)-(p)56

\begin{tabular}{|l|l|l|}
\hline Fjolnis pings an hingat & $\begin{array}{l}\text { 'assembly.GEN of Fjǫlnir } \\
\text { (Odin)... }\end{array}$ & Hást Lv $3^{\mathrm{IV}} .6$ \\
\hline $\begin{array}{l}\text { Gǫndlar pings, með } \\
\text { gengi }\end{array}$ & $\begin{array}{l}\text { 'assembly.GEN of Gǫndul } \\
\text { (valkyrie)... }\end{array}$ & Hskv Útdr $7^{\mathrm{II}} .7$ \\
\hline odda ping ${ }^{12}$ í eyddri & 'assembly of points... & Sigv Víkv 2 .3 \\
\hline odda pings, ok eyddi & 'assembly.GEN of spears... & Anon Pl $48^{\mathrm{VII}} .3$ \\
\hline darra ping ${ }^{13}$ við drengi & 'assembly of darts... & HSn Lv $2^{\mathrm{II}} .7$ \\
\hline
\end{tabular}

That 2 of 5 examples with ping have a proper-name determinant could, of course, be an accident of the small sample. As was pointed out in Part II, the base-word veðr is not uncommonly found with a proper-name determinant in two-element kennings: if the examples of basic type 1(p)YyXx are not included, veðr still appears with a proper-name determinant in 11 of the 28 remaining examples of basic kennings surveyed by Meissner (MNDF II: 55). The prominence of proper names could therefore here, too, potentially be an accident of the data, although the appearance of 4 proper names in 5 examples is directly comparable to proper names occurring with 8 of 10 examples with veðr in basic type $1(\mathrm{p}) Y y X x$ battlekennings (MNDF II: 54-55). These are the only two examples of Laufi as

11 Finnur Jónsson interprets the base-word $v a ð r$ (from vá = 'a piece of cloth') making this an armour-kenning, as also done with the kenning Hegna veðr (1a.iii), but the manuscripts generally present veðr.

12 One manuscript reads hríð.

13 This kenning is commonly represented as a compound in editions of the verse, although it does not appear consistently as a compound in manuscript variants; as in the pilot study, kennings in generative constructions are editorially represented as two words here. 
a determinant for veðr in Meissner's survey (1921: 181). This makes it less likely that the two examples here are coincidental and also draws attention to the phonetic similarity of the words in positions 5-6, which carry both alliteration and skothending rhyme (i.e. not including the vowel) with the determinant. It also warrants pointing out that Laufi belongs to the same grammatical category as other proper names, but aligns semantically with the category 'implements of battle' rather than with 'mythic agents of battle'. If only mythic agents of battle are counted, the relative frequency of occurrences with veðr here is approximately that observed in Meissner's data. However, proper-name determinants do not appear common for ping and the occurrence of names for agents of battle in $40 \%$ of the examples here remains striking, even if the dataset is too small to be conclusive. This raises a methodological point for the data reviewed here.

Within examples with veðr, the sword-name Laufi carries both alliteration and rhyme (1a.i-ii), increasing the probability that this choice of determinant is primarily or exclusively attributable to meeting phonic demands. Similarly, Hogni (1a.iii) carries alliteration and aðalhending-rhyme (i.e. with the participation of the vowel), and Hogni appears to be the only attested determinant in any battle-kenning capable of rhyme in - ggn- (cf. Björnsson -2001). It thus also seems probable that the choice of Hogni is related to meeting phonic demands. When 4 of these 10 examples exhibit recurrence of a determinant, it warrants observing that Hogna veðr could be a type of variation in $h$-alliteration associated with Hamðis veðr (1a.iv). This possibility may find some support in the observation that these are the only two names of heroes or kings found in this basic type (although cf. Laufi). It therefore seems probable that lexical choice or variation is directly related to meeting phonic demands, which would have motivated and conditioned such variation. Although the prominence of proper names occurring with veðr might in one respect appear the most prominent in the data, it could also be attributable, at least in part, to realising the metricstructural type through verbal systems of association identifiable with quite specific personal names rather than with a broad semantic category of heiti.

\section{Base-Words in Four Examples}

The base-words leikr = 'play, sport, game' and seiðr = 'magic, sorcery' are each found in four examples. Leikr was found in the pilot study to be a midfrequency base-word in battle-kennings in dróttkvott but still among the nine most frequent base-words, which were each able to meet a different pattern of 
alliteration (Frog 2015a). Alliteration (except for its avoidance) is not however a determinant on base-words in type $\mathrm{YyX}(\mathrm{p}) 56$ battle-kennings. It is therefore not particularly surprising to find leikr in a number of examples here even when more frequent base-words associated with common patterns of alliteration (e.g. hrið) are not. More striking is the otherwise infrequent base-word seiðr, of which Meissner (1921: 197) lists only five examples as a battle-kenning base-word (which does not include (2b.ii) below) or two in addition to the examples of type $\mathrm{YyX}(\mathrm{p}) 56$ battle-kennings. Of the four examples here, two are lausavisur attributed to the same poet preserved in the same prose text. The prominence of the genitive inflection of seiðr is striking in the metricstructural type, three exhibit the same rhyme-word (2b.i-ii, iv), and two have the same determinant (2b.ii-iii).

\section{(2a) Yy-leik-(p)56}

\begin{tabular}{|l|l|l|}
\hline Yggjar leik hvé auka & 'play of Yggr (Odin)... & Anon Pl 34 ${ }^{\mathrm{VII}} .3$ \\
\hline Hildar leik und skildi & 'play of Hildr (valkyrie)... & PjóðA Sex 2 .6 \\
\hline Hildar leik, pars hvassir & 'play of Hildr (valkyrie)... & Anon Krm $14^{\mathrm{VIII}} .7$ \\
\hline eggja leik ${ }^{14}$ við seggi & 'play of blades... & pormÓl Ár $5^{\mathrm{IV}} .2$ \\
\hline
\end{tabular}

(2b) Yy-seiðs-(p)56

\begin{tabular}{|l|l|l|}
\hline Fjǫlnis seiðs á heiði & 'magic.GEN of Fjǫlnir (Odin)...' & Eviðs Lv 6 $6^{\mathrm{V}} .6$ \\
\hline loggðis seiðs ${ }^{15}$ á heiði & 'magic.GEN of the stabber (sword)...' & Eviðs Lv $5^{\mathrm{V}} .2$ \\
\hline lǫgðis seið(s) ${ }^{16}$ af láði & 'magic(.GEN) of the stabber (sword)... & Phorn Gldr $8^{\mathrm{I}} .7$ \\
\hline vigra seiðs of heiðar & 'magic.GEN of spears ${ }_{2} . .$. & Gkǫrt Lv $1^{\mathrm{IV}} .6$ \\
\hline
\end{tabular}

The set of examples is small, yet it is striking that 3 of 4 leikr examples have names of agents of battle as determinants. The recurrence of the valkyrie-name Hildr is consistent with Meissner's (1921: 199) data: he shows 7 examples of Hildr among the 13 simple kennings using leikr with a proper-name determinant, or 7 of 11 with a proper name of a mythic agent of battle. According to his data, there is only one example of combination with a different valkyriename and this is his only example of an Odin-name as a determinant. The only other name for a mythic (or mytho-heroic) agent that Meissner lists is Freyr (gen. Freys) in two examples, which would not be metrically acceptable

14 The manuscript variant fund = 'meeting' would not affect this line metrically or semantically.

15 The variant skeiðs appears in manuscripts: skeið means 'a race; a course; a period of time'.

16 The inflection of seiðr in this line varies in the manuscripts (one variant also reads eiðs = 'oath.GEN'); interpretations of the syntax of the helming do not seem to have been consistent. 
in this formula. The valkyrie-name Hildr may be indexed as a determinant for leikr within the register generally. It should therefore not be assumed that the lexical parallel in examples (2a.ii-iii) is indicative of a direct relation between lines or of the crystallisation of the verbal formula within this basic type (cf. MNDF I: 124-125). The use of Fjolnir with seiðr is the only example of seiðr as a battle-kenning base-word listed by Meissner with a proper-name determinant. Within these eight examples, half have proper-name determinants.

\section{Base-Words in Three Examples}

The base-words peyr = 'thaw; thawing wind, breeze', él = 'squall' and gnýr = 'roar' are each found in three examples. $E$ l was the highest-frequency base-word observed in the pilot study (33 of 340 examples, including all metric-structural types); gnýr was also a high-frequency base-word and peyr was mid-frequency. All examples with peyr or gnýr are inflected in the genitive singular. This highlights that the use of these (and other) terms in the formula is morphologically conditioned: the base-word should be a heavy monosyllable, which limits the use of these terms to the inflectional forms $-r$ and genitive $-s$, although only the genitive inflection is met in the data.

\section{(3a) Yy-peys-456}

\begin{tabular}{|l|l|l|}
\hline Gondlar peys, ok Grími & 'breeze.GEN of Gondul (valkyrie)... & PKolb Gunndr $1^{\mathrm{V}} .3$ \\
\hline Gondlar ${ }^{17}$ peys ok Eyjar & 'breeze.GEN of Gondul (valkyrie)... & HSt Rst $11^{\mathrm{I}} .4$ \\
\hline hlífar peys sem Eyjar & 'breeze.GEN of the shield...' & Anon Óldr $12^{\mathrm{I}} .2$ \\
\hline
\end{tabular}

(3b) Yy-él(s)-(p)56

\begin{tabular}{|l|l|l|}
\hline Hristar éls, ór kistu & 'squall.GEN of Hristr (valkyrie)... & EGils Guðkv $34^{\mathrm{IV}} .6$ \\
\hline hjorva éls á halsi & 'squall.GEN of swords $\ldots$ & Kolb Lv $1^{\mathrm{IV}} .3$ \\
\hline nadda él en, nýla & 'squall of barbs... & Sigv Frag $1^{\mathrm{III}} .3$ \\
\hline
\end{tabular}

(3c) Yy-gnýs-(p) 56

\begin{tabular}{|c|c|c|}
\hline sverða gnýs at frýja & 'roar.GEN of swords $1 . .$. & Sigv Nesv $4^{\mathrm{I}} .2$ \\
\hline hjǫrva gnýs ok skýjum & 'roar.GEN of swords ${ }_{2} . . '$ & HSt Frag $1^{\mathrm{I}} .6$ \\
\hline odda gnýs við œsi & 'roar.GEN of points...' & Anon (SnE) $5^{\text {III }} .1$ \\
\hline
\end{tabular}

17 The manuscript reading "gvnnlar" could also be emended to the valkyrie-name Gunnar without compromising the metricality of the line, although Gondlar is statistically more probable. 
The name Gondul appears twice as a determinant with peyr (3a.i-ii) and the third example (3a.iii) shares a rhyme-word with one of these (3a.ii). Meissner (1921: 182) lists only one of these (3a.i) and only a total of two examples of peyr with the name of a mythic agent of battle as a determinant. The lines are structurally similar and both appear in verses with a number of contextually relevant pronouns, increasing the likelihood that they are somehow related. The two examples in which peyr carries rhyme with the toponym Eyjar are in half-stanzas that are thematically related as well as being proximately presented in the same manuscript and potentially have quite a direct relationship of poets adapting socially circulating verses. ${ }^{18}$ The three examples with peyr should thus be considered to reflect a closer relationship between full-line models, as has been found also for uses of peyr in other metric-structural types. ${ }^{19}$ The remaining examples present only one proper name: the valkyrie-name Hrist (16b.i), which accomplishes aðalhending-rhyme in addition to alliteration. There appear to be only two attested battle-kenning determinants that can accomplish rhyme in -ist- and both are valkyrie-names: Hrist and Mist (cf. Björnsson -2001). It is probable that phonic demands have conditioned this lexical choice. Although proper-name determinants are not distributed evenly across these examples, they account for 3 of 9 or one third of them.

\section{Base-Words in Fewer than Three Examples}

Examples with base-words that occur only twice or in a single example are particularly difficult to assess. The base-words dómr $=$ 'doom, judgement, ${ }^{20}$ mót $=$ 'meeting', hregg = 'rainy wind, tempest' and regn = 'rain' are each found twice. With the exception of dómr, these were all found to be mid-frequency base-

18 The possibility that the individual transcribing both verses has been responsible for remembering them in relationship to one another must also be considered, although the difference between $o k$ and sem in the light particle (cf. Jónsson $1967 \mathrm{~B}_{\mathrm{I}}: 570$ ) would seem to be counterevidence to any suggestion that the person writing out the verses was consciously repeating material across poems.

19 The pilot study revealed three examples of basic type YX3456 battle-kennings in which peyr carried rhyme with a two-element toponym of which -eyjar was the second element (Frog 2015a).

20 It is interesting also to note that the line heiðins dóms at háða (Tindr Hákdr $7^{\mathrm{I}}$.7) in the same poem as (4a.i) aligns with this structure although heiðinn = 'heathen' appears rather than a kenning determinant. Also interesting is the line Iðja dóms á miðjum (PormÓl Ár $2^{\mathrm{IV}} .6$ ) = 'judgement.GEN of Iði (giant)...' in which the same basic type with dómr forms a gold-kenning. 
words in the pilot study. Only the two examples with the base-word hregg = 'rainy wind, tempest' present a potential aðalhending-rhyme collocation, and this collocation is not specific to the basic type,$^{21}$ so this pair could simply reflect independent uses of a common compositional resource. The remaining 5 base-words found in one example each were low-frequency in the pilot study (i.e. found in ca. $1 \%$ or less of examples). The kenning morð holða = 'murder of men' is generally unusual. What is intriguing to note here is that all but one of these 13 examples exhibit a genitive inflectional $-s$ on an already heavy syllable.

\section{(4a) YyXx(p)56 with base-words attested twice}

\begin{tabular}{|l|l|l|}
\hline Svǫlnis ${ }^{22}$ dóms, í rómu & $\begin{array}{l}\text { 'judgement.GEN of Svǫlnir } \\
\text { (Odin)... }\end{array}$ & HSt Rst $5^{\mathrm{I}} .8$ \\
\hline Gǫndlar dóms ${ }^{23}$ at glaumi & $\begin{array}{l}\text { 'judgement.GEN of Gǫndul } \\
\text { (valkyrie)... }\end{array}$ & Tindr Hákdr $5^{\mathrm{I}} .3$ \\
\hline Hlakkar móts - til blóta & $\begin{array}{l}\text { 'meeting.GEN of Hlǫkk } \\
\text { (valkyrie)... }\end{array}$ & Eskál Vell $15^{\mathrm{I}} .2$ \\
\hline Qrva móts ... ${ }^{24}$ & 'meeting.GEN of arrows...' & Anon Pl $58^{\mathrm{VII}} .8$ \\
\hline geira hregg við seggi ${ }^{25}$ & 'rainstorm of spears .... & Phorn Gldr $5^{\mathrm{I}} .2$ \\
\hline vápna hreggs - fyr seggjum & 'rainstorm.GEN of weapons... & Porm Porgdr $3^{\mathrm{IV}} .2$ \\
\hline odda regns við pegna & 'rain.GEN of points.... & Anon Gyð $5^{\mathrm{VII}} .4$ \\
\hline geira regns í gognum & 'rain.GEN of spears .... & Stúfr Stúfdr $8^{\mathrm{II}} .3$ \\
\hline
\end{tabular}

21 Cf. Anon Leið ${ }^{\mathrm{VII}} .4$, GOdds Lv $7^{\mathrm{IV}} .2$; GrHj Lv $1^{\mathrm{IV}} .6$.

22 One manuscript reads snæelinns = 'snow-serpent' = 'sword'.

23 This reading follows the manuscript text, which has been emended to Gondlar dóm ${ }^{*}$ in the SPSMA edition.

24 The rest of the line cannot be read, but the metric-structural type of the kenning seems unambiguous.

25 One manuscript has a variant line geirs hreggviðar seggi which preserves the basic kenning as geirs hregg- = 'tempest of the spear', reinterpreting the preposition $v i ð=$ 'with' as an inflected form of $v i ð r=$ 'wood, tree' to form a warrior-kenning 'spear's tempest-tree' = 'battle-tree' = 'warrior'. This variation is metrically well-formed but changes the metrical positions of words by moving the inflectional syllable of geir-a to við-ur. 
(4b) YyXx(p)56 with base-words attested once

\begin{tabular}{|l|l|l|}
\hline Pundar gráps ${ }^{26}$ með vopnum & $\begin{array}{l}\text { 'sleetstorm.GEN of Pundr } \\
\text { (Odin)... }\end{array}$ & Bjhít Lv $18^{\mathrm{V}} .6$ \\
\hline hǫlða morðs ${ }^{27}$ ok halda & 'murder.GEN of men...' & Eskál Vell $20^{\mathrm{I}} .3$ \\
\hline odda $^{28}$ frosts fyr austan & 'frost.GEN of points... & Sigv Nesv $3^{\mathrm{I}} .3$ \\
\hline premja storms, at Ormi $^{\text {prem }}$ & 'storm.GEN of swords... & HSt Rst $21^{\mathrm{I}} .4$ \\
\hline malma galdrs, at halda & 'incantation.GEN of metals...' & GunnlI Lv $3^{\mathrm{V}} .2$ \\
\hline
\end{tabular}

Among base-words found fewer than three times, 4 of the 13 examples or nearly one third exhibit the use of proper names. In two cases, this is with dómr, yet even if only one of these is counted, 3 of 12 cases would still be $25 \%$, and quite a high proportion. Although the group of examples remains small, this higher frequency is generally consistent with proper name use in basic type $\mathrm{YyX}(\mathrm{p}) 56$ battle-kennings.

\section{Metrical Entanglement of the Lexicon}

Before concentrating attention on the use of proper names in type $\mathrm{YyX}(\mathrm{p}) 56$ battle-kennings, it warrants observing that this basic type seems to exhibit general indications of the metrical entanglement of the lexicon. Although no single base-word predominates, the dataset shows a striking proportion of base-words in multiple examples: two base-words are found in five examples each; two in four examples each; three in three examples each; four in two examples each, and only five singly. This could be a natural statistical outcome with some high-frequency battle-kenning base-words, but cannot easily be dismissed, for example, in the case of seiðr. In contrast, the second most frequent base-word according to the pilot study, hrí = 'storm' (cf. also hagl = 'hail' etc.), is metrically viable but not found at all in this data (with the exception of one manuscript variant of 1 b.iii). The patterns in base-word use are thus suggestive

26 The manuscript reads garps = 'warrior' but the required rhyme in the line and the semantic context suggest this is a scribal error.

27 This example is uncertain. One manuscript reads "morz" while others read Njgrðr, which can be read as a kenning for ruler. Finnur Jónsson places the kenning holda morðs in his edition of the stanza whereas it is presented as a note in the SPSMA edition.

28 One manuscript reads eggja = 'of edges' here, which would be consistent with the battle kenning and the line would remain metrically well-formed. One manuscript reads orð $a=$ 'of words', which would be metrically well-formed but not produce a battle kenning. 
of general conventions of preferred word choice. Some evidence of metrical entanglement of the lexicon may also be observed for determinants: odd $r=$ 'point' is found in five examples; the valkyrie-name Gondul is found in four examples; geirr = 'spear' in three examples; ${ }^{29}$ five base-words are found twice (Fjolnir, Hildr, hjorr, Laufi, logðir) and eighteen singly. Identifying certain heiti as potentially lexically preferred for realising type $\mathrm{YyX}(\mathrm{p}) 56$ battle-kennings is to suggest that they are metrically entangled with the semantic formula, as was the case with vápn = 'weapon' as a determinant in 12 of 80 examples of basic type 1(p)YyXx (MNDF II: 48-49, 64-65). Comparison with vápn seems especially relevant to consider in the case of the determinant $o d d r$ here, found in five examples with four different base-words (1b.iii-iv, 3c.iii, 4a.vii, 4 b.iii). Of 40 examples, 24 exhibit a base-word and/or determinant found four times or more in the data $(60 \%)$ and 31 exhibit a base-word and/or determinant found three times or more (over 75\%). Although no single base-word or determinant is found in more than 5 examples, there are five pairs of lexically identical kennings (1a.i-ii, 1b.iii-iv, 2a.ii-iii, 2b.iii-iv, 3a.i-ii), which accounts for 1 in 4 examples.

When considering the metrical entanglement of the lexicon, morphology is a relevant factor. The morphology of determinants is necessarily a genitive inflection in the formation of kennings in this basic type. Metrically entangled determinants are therefore necessarily only those which form a two-syllable word in a genitive inflection and it is easily taken for granted that geirr = 'spear', for example, appears only in the genitive plural geira and never in the genitive singular geirs. More striking is the fact that, in 29 of the 40 examples, the base-word is in the genitive inflection (although the inflection of example 2b.iii with seiðr exhibits morphological manuscript variation). The preponderance of use in the genitive may be in large part associated with a broad pattern of use of this formula as a determinant in complex warrior-kennings of 3-4 elements, leading to metrical entanglement of the kenning formula at the level of the syntax of the helming. That does not, however, account for all of the genitive uses. The prominence of genitive inflections is more striking owing to the generally unusual appearance of base-words having a heavy monosyllabic stem that is further inflected with a genitive $-s$. As pointed out above, when not in compounds, a heavy monosyllable in a genitive $-s$ inflection is used especially in position 3 . In the dataset, more than half of the examples

\footnotetext{
29 Geirr was the most frequent basic determinant in the pilot study, found in ca. $7 \%$ of the examples (Frog 2015a); its appearance here in 3 of 40 examples (7.5\%) appears statistically consistent with its general presence in the corpus and most likely is not an outcome of metrical entanglement with the formula.
} 
(23 of 40) have base-words of this special (superheavy) weight. The limited range of positions in which such a syllable was desirable in the rhythm of a line may have converged with this kenning formula leading to a tendency or preference to complete the kenning in this way and to inflect the base-word in the genitive case more generally.

The genitive inflection may also be connected to the metrical entanglement of specific vocabulary. It was also noted that the use of the base-words gnýr and peyr with light monosyllabic stems was morphologically conditioned to produce a heavy monosyllable. Although both peyr (3a) and gnýr (3c) would be metrically viable in the nominative, only the genitive inflection is found in the data. The morphology of these base-words may potentially have been metrically entangled with their use in this formula, noting that these are the only basewords in the dataset with a light-syllable stem. It also becomes striking that leikr (2a) is the only base-word not found in the genitive inflection, accounting for 4 of the 11 cases in which the base-word is not in the genitive case. Other basewords are found in the genitive roughly half the time or more: veðr (1a) is found in the genitive in 2 of 5 examples; ping (1b) in 3 of 5 examples; él (3b) in 2 of 3 examples; hregg (4a.v-vi) in 1 of 2 examples; seiðr (2b) in all but a manuscript variant of one example (2b.iii); all other base-words are only found in the genitive inflection. The base-word seiðr, attested with equal frequency to $l e i k r$, also is potentially linked to use in the genitive inflection. Among the 40 examples, all base-words are masculine or neuter monosyllabic strong nouns. Feminine monosyllabic strong nouns such as the high-frequency hrí = 'storm' and midfrequency skú $r=$ 'shower' are completely absent. ${ }^{30}$ Feminine strong nouns receive a genitive singular inflection -ar (hriðar, skúrar). Their absence is a potential indicator that the metrical entanglement of the lexicon for realising the formula was limited to nouns that remained a monosyllable in the genitive inflection - i.e. the formula was not conventionally completed with base-words that could not also be used in the genitive. Patterns in the morphology of base-words remain obscure without further investigation. Nonetheless, there is a possibility that the metrical entanglement of an individual base-word potentially extended to the case in which it was used and that the declension of the noun was a determinant on whether it became entangled with the formula. The difficulty that arises is that the dataset remains quite limited to fully assess the patterns of use of individual base-words. ${ }^{31}$

\footnotetext{
30 I am thankful to an anonymous peer-reviewer for this observation.

31 It was observed above that the kennings Hogna veðr (1a.iii) and Hamðis veðr (1a.iv) could potentially be related through the tradition in some way. Neither of these examples is in the
} 
When considering the metrical entanglement of language, it may warrant explicitly observing that the internalisation of a formula of basic type $\mathrm{YyX}(\mathrm{p}) 56$ would occur through participation in language practice. The internalisation of the preferred heiti for completing the formula and how these were used would develop from the generalisation of experience concerning which heiti were used effectively without violation of the meter. In the case of determinants, that means heiti with a heavy stressed syllable followed by one additional syllable when in the genitive inflection. In the case of base-words, that meant heit $i$ that formed a heavy monosyllable in the syntax of the verse. The data suggests that the capacity to form a heavy monosyllable in the genitive inflection was a determinant on lexical preference (as opposed to hríð, gen. hríðar) and especially those forming a monosyllable of special (superheavy) weight. Viewed in this light, it should be expected that an individual fluent in the register would develop indexical associations between the formula and metrically viable vocabulary without needing to resort to reflective consideration of which among the great diversity of heiti would work in certain positions. It appears that use of the battle-kenning formula of basic type $\mathrm{YyX}(\mathrm{p}) 56 \mathrm{had}$ socially developed indexical associations with vocabulary with which the kenning would be formed. In other words, the choice of using the formula linked to vocabulary appropriate for completing it. This type of association would have functioned cognitively in the mind of individual poets: rather than being a function of 'remembering', it would function at the level of how the individual processed language in use. The association of the formula with specific vocabulary must have been internalised through patterns of language use in the poetry. Those patterns of language use are also reflected as preferred lexical choices in the corpus that can be observed in analysis.

Alongside conventional elements forming the kennings, there are 9 examples of recurrent rhyme-pairs in the data (in even lines: $2 \mathrm{~b}$.i-ii and 2b.iv, 3a.ii-iii, 4a.v-vi; in odd lines: 1b.iii-iv and cf. also the rhymes in 1a.i-ii). For

genitive inflection, accounting for 2 of the 7 cases outside of the examples with leikr. Considering the potential for the inflection to become entangled with language use, the generally unusual lack of the genitive inflection here could potentially be an additional indicator that these two examples are somehow connected. If this is the case and the lack of the genitive inflection in the 4 examples with leikr is indeed a consequence of the metrical entanglement of the morphology of leikr in the formula, then these together account for 6 of 11 cases where the base-word is not in the genitive, leaving only 5 in the remaining 34 examples. On the one hand, this would significantly strengthen the case for the metrical entanglement of the base-word's morphology with the formula, but on the other hand the use of the genitive in roughly 7 of 8 examples in the rest of the dataset would leave the prominence of the genitive inflection with gnýr, peyr and seiðr as probably accidents of the limited size of the corpus. 
the most part, these rhyme-pairs exhibit complementary distribution to lexically recurrent kennings: 17 of the 40 examples or slightly less than half exhibit one or both of these. These rhyme-pairs could potentially be conventional collocations. They could also be linked more specifically to the formula. In the latter event, the rhyme collocations would also be linked in the minds of poets with preferred lexical choices for completing the formula in a flexible verbal system called a 'multiform' for the production of metrically well-formed lines (MNDF II: 53, 66). Some cases could also potentially reflect poets directly adapting a line known from another poem into a new composition as in the example of peyr-Eyjar above (see Frog 2014b: 299-301). However, it must be remembered that only a fraction of the verse circulating orally is preserved. Fluency in the poetic idiom would involve the internalisation of patterns in language use and presumably obviate the need to reflect on existing lines as specific models, making direct textual adaptation more of an exception than a rule.

The rhyme-word that recurs in positions 5-6 may carry rhyme with either the base-word or the determinant. Where rhyme is with the base-word, the rhyme-pair appears independent of a recurrent determinant; where rhyme is with the determinant, it is only found with a single base-word and linked to a lexically recurrent kenning. This apparent pattern could in part be owing to limitations of the data, but it is observed in rhyme-pairs found in roughly 1 in 4 examples. The evidence makes it probable that base-words have greater centrality in the formation of verbal systems of collocations for realising the line. In other words, base-words in basic type $\mathrm{YyX}(\mathrm{p}) 56$ battle-kennings seem to be centers around which multiforms have developed. Nevertheless, the most frequent determinants oddr, Gondul and geirr are not bound to basewords, suggesting that these are preferred choices for completing the formula more generally.

The examples of YyX(p)56 identified here also present cases of lexical parallels in the rhyme-position independent of recurrent rhyme collocations in the data. Some of these are vocabulary otherwise found in rhyme-pairs (cf. 1a.iv and 2b.i-ii, iv; 2a.iv and 4a.v-vi). Others lack such evidence of collocations in this basic type (cf. $4 \mathrm{~b}$.ii and 4b.v; a full prepositional phrase in 1a.iii and 4a.viii). This is a potential indicator that the semantic formula was not only linked to lexical material for completing the base-word and determinant but also linked to additional lexical material for completing the line. The additional material appears in some instances linked to a particular multiform. However, the present data suggests that this additional material could also be drawn on to some degree independently. It may be hypothesised that the indexical association of such material with the formula developed as part of the process of internalising the oral-poetic register. The data is quite limited 
and these considerations remain dependent on the representativeness of that data. Nonetheless, it is somewhat remarkable that, for example, evidence of a verbal system including both determinant and rhyme-collocation linked to peyr seems to be observable in only three examples of that base-word (3a) within a corpus of only 40 items.

\section{Personal Name Determinants and the Formula}

The metrical entanglement of the lexicon with basic type YyX(p)56 battle-kennings appears at least to some degree to extend to personal names of mythic beings. The valkyrie-name Hildr is used twice with leikr (2a.ii-iii) and the mytho-heroic sword-name Laufi is used twice with veðr (1a.i-ii; N.B. morphological variation in the base-word's inflection). Within such a limited corpus, it remains uncertain whether these kennings are lexically identical because of a direct adaptation of socially circulating lines, or because the verbal expressions have developed into crystallised formulae as was observed with gnýr Gunnar = 'roar of Gunnr (valkyrie)' in basic type 12(p)XYy (MNDF I: 124-125, 131), or simply because they are the outcomes of independent generative production. The Odin-name Fjolnir is found with two different base-words in its two uses (1b.i, 2b.i), but the same phenomenon has also been found in the previous studies for the valkyrie-names Hildr (MNDF II: 54-56), Gunnr (just noted) and also Gondul (MNDF II (pp. 55, 57-58), as well as for the hero-name Heðinn (MNDF II: 52, 57). These latter four names are all fairly common in the production of battle-kennings (cf. Björnsson -2001), which is why Hildr is difficult to assess. In contrast, Fjolnir seems to be rare in battle-kennings: it is found in the two simple battle-kennings here (3b.i, $4 \mathrm{~b} . \mathrm{i})$ and as a determinant in kennings for shield (Hskv Utdr $1^{\mathrm{II}} .2$ ) or sword (Tindr Hákdr $1^{\mathrm{I}} .3$ ) that then form complex battle kennings (cf. Björnsson -2001). This makes it less probable that the two examples here are merely coincidental. In addition, four examples present the valkyrie-name Gondul used with three different basewords (1b.ii, 3a.i-ii, 4a.ii). Although Gondul is a more common valkyrie-name according to the pilot study (Frog 2015a), the four examples here are twice the number of appearances of Gondul in other metric-structural types reviewed in Parts I and II of this series. ${ }^{32}$ In this series of case studies, there are only two other cases in which a personal name is found more than twice in the data for

\footnotetext{
32 See MNDF I (pp. 126, 130-131), which also discusses the relative uses of this name and the valkyrie-name Gunnr; see also MNDF II (pp. 55, 57-58).
} 
a type: the five examples of the crystallised formula gnýr Gunnar in basic type 12(p)XYy along with its parallel use with $d y n r=$ 'din' (on which, see MNDF I: $124-125,131)$ and the three examples of the common valkyrie-name Hildr among the 80 examples of type 1(p)YyXx (MNDF II: 54-56). Although Gondul seems to be connected to a compositional system in its two uses with peyr, its presence still seems pronounced as appearing in 1 of 10 examples. Together, the recurrent names Gondul, Hildr, Laufi and Fjolnir in YyX(p)56 account for 10 examples or $25 \%$ of the data. This prominence makes it more difficult to dismiss as a simple anomaly.

Examples with Gondul and Fjolnir could, like those with oddr, be symptomatic of patterns of preferential word-choice at a more general level of the metric-structural type, yet the use of proper-name determinants is not concentrated in these few terms. The case study on basic type 1(p)YyXx (MNDF II) showed that proper names could be indexed as a preferred category of determinant for certain base-words within a metric-structural type. A look across the data reviewed here could offer an initial impression that this is also the case for veðr in $\mathrm{YyX}(\mathrm{p}) 56$ battle-kennings (1a), where proper names appear as determinants in four of five cases. Here, however, the two uses of Laufi and the corresponding uses of Hogni and Hamðir could reflect much more specific associations. Such specific associations may also be behind uses of Gondul with peyr (3a.i-ii). Uses of Hildr with leikr are more ambiguous (2a.ii-iii) because these could be an outcome of a more general association of Hildr as a determinant with leikr as a base-word, observing that leikr does not carry either alliteration or rhyme in these examples and thus there is no metrical motivation for its use in these lines (but cf. its use in skothending rhyme in 2a.i). In any case, use of proper names does not appear exclusively concentrated with certain base-words. These three base-words are connected with only 6 of the 10 uses of Gondul, Hildr, Laufi and Fjolnir, or slightly more than half. The recurrence of base-words and determinants is thus intersecting and complementary rather than exhibiting a direct correlation.

In addition to examples with these four names, 8 additional examples present proper names as determinants that are used only once. Thus 17 of the 40 examples (42.5\%) exhibit personal names as determinants, 15 of which (37.5\%) are names for agents of battle. If examples with veðr, leikr and peyr are removed from the data, this still leaves 8 of 28 examples with names of mythic agents of battle as determinants, or close to $30 \%{ }^{33}$ This is three times what might be expected as average on the basis of the pilot study. Whereas basic type 1(p)

33 If examples with domr are also removed, the numbers only drop to 6 out of 26 or $23 \%$. 
YyXx showed that mythic personal names could become preferred for determinants when using certain base-words in the semantic formula, variation in evidence of basic type $\mathrm{YyX}(\mathrm{p}) 56$ suggests that such mythic names could become more generally preferred as determinants for realising the metrically entangled formula.

The category of determinant that is metrically entangled here may not be that of proper names as such. Among the 17 personal names, names for Odin and valkyries predominate: 5 Odin-names, 8 valkyrie-names, 2 uses of the heroic sword-name Laufi, and 2 hero-names. Thus slightly more than $75 \%$ are names for mythological beings. This proportion rises to more than $85 \%$ if the sword-heiti Laufi is excluded and only names for agents of battle are considered. The two hero-names (1a.iii-vi) may be linked as rhyme-based variations for accomplishing $h$-alliteration collocated narrowly with veðr (along with Laufi, which carries alliteration and rhyme in both cases). Although there are so few examples that it is difficult to assess the significance of these uses with $v e ð r$, the heroic names do not appear distributed through the data in the same way as names for Odin and for valkyries. ${ }^{34}$ If the data available on this formula is generally representative and it is also correct to view the two heroic personal names as narrowly collocated with a single base-word, then this would suggest that the category of determinants linked to the formula of type $\mathrm{YyX}(\mathrm{p}) 56$ is 'mythological agents of battle' or Odin-names and valkyrie-names.

The metrical entanglement of this category of determinant needs to be considered in relation to the evidence of the metrical entanglement of the lexicon and also the concentration of proper-name determinants in conjunction with certain base-words. The most striking aspect of the metrical entanglement of the lexicon is that it is so apparent in what is, practically speaking, a relatively small set of 40 examples. If a greater number of examples were available - as with the 80 examples of basic type 1(p)YyXx surveyed in MNDF II - then it is probable that better images of indexing between certain base-words and determinants (or its lack) would become visible as would the verbal systems and variation of multiforms (or their absence). It nevertheless remains striking that preferred lexical items such as oddr and Gondul seem to have distributed use. If the preserved corpus is considered more or less representative of the relative proportions of metric-structural kenning types to which individuals

\footnotetext{
34 Comparison can be made with personal names in examples of basic type 1(p)YyXx: there are an equal number of examples with Odin-names and mytho-heroic names (7 each; cf. also 10 valkyrie-names) and the heroic names are distributed through the data rather than concentrated.
} 
were exposed when internalising the register, ${ }^{35}$ then basic type $\mathrm{YyX}(\mathrm{p}) 56$ battle-kennings probably had only about half the token frequency of 1(p)YyXx. In other words, people only used it about half as much. This means that the use of YyX(p)56 battle-kennings was internalised through a much narrower range of models. Regarded in this light, the prominence of lexically identical kennings and rhyme collocations recurrent in the data can be considered outcomes of a narrower range of models with which this basic type was realised. ${ }^{36}$ Of course, this narrower range of models from which use of the formula is internalised can only be partly attributed to the lower token frequency. The range would also in some sense have been socially built into the conventional ranges of variation of how the formula was used - much as basic type 12(p)XYy battlekennings were seen to center quite tightly around only two of a base-words attested for basic type 12(p)XYy battle-kennings in MNDF I. Nevertheless, the tightness of the verbal elements realising type $\mathrm{YyX}(\mathrm{p}) 56$ battle-kennings seems linked to its narrower use that - for whatever reason - prominently maintained a constrained set of preferred lexical material as metrically entangled with the basic type's formula. Whereas basic type 1(p)YyXx battle-kennings exhibited preferred heiti for realising the formula and the preference for names of mythic agents of battle as determinants for particular base-words, basic type $\mathrm{YyX}(\mathrm{p}) 56$ battle kennings suggest that preferred heiti and the preferred semantic category of names for mythological beings were complementary and without such structured relations.

\section{Postscript}

This concludes the third case study in this series. Each of these case studies has concentrated on a specific metric-structural type in order to demonstrate

\footnotetext{
35 Any such estimate is necessarily speculative, especially noting that $a$ ) only certain parts of the oral-poetic culture are represented in the data; $b$ ) we cannot at all assess the token frequency with which individual texts were encountered/used (i.e. we count each text once whereas some texts would be experienced hundreds of times and others only exceptionally); and $c$ ) there is presently no framework for considering registral variation by social practice and poetic genre (i.e. whether certain models had quite narrow contexts of usage).

36 In the pilot study, it was found that low-frequency basic types could also exhibit lexical correspondences even where there were less than five examples. This was interpreted as evidence that either models were drawn directly from socially circulating verses or that in formulae of quite limited usage the lexicon was more inclined to become metrically entangled (Frog 2015a). Such cases were, it should be noted, far less frequent than basic type YyX(p)56 battle-kennings.
} 
the formulaicity of kennings of the respective type and also to explore how the lexicon has become metrically entangled with use of the particular formula. The fourth part in the series will shift focus from individual metric-structural types to the generalisations about compositional practice in the skaldic register that can be drawn by looking across them. On the one hand, the final part in this series will consider the implications for formulaic language use and multiforms as resources in composition. On the other hand, that discussion will consider implications for understanding the historical construction of the registral lexicon, its categories of heiti, and especially the personal names of mythological beings in that lexicon. ${ }^{37}$

\section{References}

Agha, Asif 2007. Language and Social Relations. Cambridge: Cambridge University Press.

Árnason, Kristján 1991. The Rhythms of dróttkvætt and Other Old Icelandic Metres. Reykjavík: University of Iceland, Institute of Linguistics.

Björnsson, Eysteinn -2001. "Lexicon of Kennings and Similar Poetic Circumlocutions: The Domain of Battle”. URL: https://notendur.hi.is// eybjorn/ugm/kennings/ kennings.html

Clunies Ross, Margaret (ed.) 2007. Poetry on Christian Subjects (2 vols.). (Skaldic Poetry of the Scandinavian Middle Ages 7). Turnhout: Brepols.

Clunies Ross, Margaret; Gade, Kari Ellen; Marold, Edith; Nordal, Guðrún; Whaley, Diana; Wills, Tarrin 2012. General Introduction. In: Whaley, Diana (ed.), Poetry from the Kings' Sagas I: From Mythical Times to c. 1035 (2 vols.). Turnhout: Brepols, xiii-xciii.

Egilsson, Sveinbjörn; Jónsson, Finnur 1931. Lexicon poeticum antiquæe linguæe septentrionalis. Ordbog over det norsk-islandske skjaldesprog. $2^{\text {nd }}$ edn. København: S. I. Møllers.

Foley, John Miles 1995. The Singer of Tales in Performance. Bloomington: Indiana University Press.

\footnotetext{
37 Research presented here has been accomplished within the framework of the Academy of Finland Project "Oral Poetry, Mythic Knowledge and Vernacular Imagination" of Folklore Studies, University of Helsinki.
} 
Foley, John Miles; Ramey, Peter 2011. Oral Theory and Medieval Studies. In: Reichl, Karl (ed.), Medieval Oral Literature. Berlin: de Gruyter, 71-102.

Frog 2009. Speech-Acts in Skaldic Verse: Genre, Formula and Improvisation. In: Dewey, Tonya Kim; Frog (eds.), Versatility in Versification: Multidisciplinary Approaches to Metrics. (Berkeley Insights in Linguistics and Semiotics 74). New York: Peter Lang, 223-246.

Frog 2014a. Degrees of Well-Formedness: The Formula Principle in the Analysis of Oral-Poetic Meters. In: RMN Newsletter 8, 68-70.

Frog 2014b. Oral Poetry as Language Practice: A Perspective on Old Norse dróttkvoett Composition. In: Huttu-Hilttunen, Pekka et al. (eds.), Song and Emergent Poetics Laulu ja runo - Pesnja i vidoizmenjajushhajasja poetika. Kuhmo: Juminkeko, 279-307.

Frog 2014c. Mythological Names in dróttkvœett Formulae I: When is a Valkyrie Like a Spear? In: Studia Metrica et Poetica 1(1), 100-139.

Frog 2014d. Mythological Names in dróttkvatt Formulae II: Base-Word-Determinant Indexing. In: Studia Metrica et Poetica 1(2), 39-70.

Frog 2015a (forthcoming). Metrical Entanglement and dróttkveett Composition - A Pilot Study on Battle-Kennings. In: Árnason, Kristján; Aðalsteinsson, Ragnar Ingi; Eypórsson, Pórhallur; Carey, Stephen Mark (eds.), Approaches to Germanic Metre [working title]. Reykjavík: University of Iceland Press.

Frog 2015b (forthcoming). Registers of Oral Poetry. In: Agha, Asif; Frog, Registers of Communication. (Studia Fennica Linguistica). Helsinki: Finnish Literature Society.

Gade, Kari Ellen 1995. The Structure of Old Norse dróttkvætt Poetry. Ithaca: Cornell University Press.

Gade, Kari Ellen (ed.) 2009. Poetry from the Kings' Sagas II: From c.1035 to c.1300 (2 vols.). (Skaldic Poetry of the Scandinavian Middle Ages 2). Turnhout: Brepols.

Halliday, Michael A. K. 1978. Language as Social Semiotic: The Social Interpretation of Language and Meaning. London: Edward Arnold.

Jónsson, Finnur (ed.) 1967. Den Norsk-Islandske Skjaldedigtning A-B. København: Rosenkilde \& Bagger.

Kuhn, Hans 1983. Das Dróttkvoett. Heidelberg: Carl Winter.

Lord, Albert Bates 1960. The Singer of Tales (Harvard Studies in Comparative Literature 24). Cambridge: Harvard University Press. 
Marold, Edith 1983. Kenningkunst: Ein Beitrag zu einer Poetik der Skaldendichtung (Quellen und Forschungen zur Sprach- und Kulturgeschichte der germanischen Völker, Neue Folge 80). Berlin: de Gruyter.

Meissner, Rudolf 1921. Die Kenningar der Skalden: Ein Beitrag zur skaldischen Poetik. Bonn: Schroeder.

MNDF I = Frog 2014c.

MNDF II = Frog 2014d.

Parry, Milman 1928. Lépithète traditionnelle dans Homère. Paris: Société d'Éditions Les Belles Lettres.

Skaldic Database. URL: http://abdn.ac.uk/skaldic/db.php.

Skj = Jónsson 1967.

SPSMA - I = Whaley 2012; II = Gade 2009; VII = Clunies Ross 2007; electronic edition $=$ Skaldic Database.

Sverdlov, Ilya V. 2015 (forthcoming). "Man is the Measure of All Things": The System of Kennings as a Tangible Object. In: RMN Newseltter 9: 18-34.

Whaley, Diana (ed.) 2012. Poetry from the Kings' Sagas I: From Mythical Times to $c$. 1035 (2 vols.). (Skaldic Poetry of the Scandinavian Middle Ages 1). Turnhout: Brepols.

Wills, Tarrin 2009. The Development of Skaldic Language. In: Ney, Agneta; Williams, Henrik; Ljungqvist, Fredrik Charpentier (eds.), Á austrvega: Saga and East Scandinavia. Preprint Papers of the $14^{\text {th }}$ International Saga Conference, Uppsala, $9^{\text {th }}-15^{\text {th }}$ August 2009. Gävle: University of Gävle, 1032-1038.

Wray, Alison 2009. Identifying Formulaic Language: Persistent Challenges and New Opportunities. In: Corrigan, Roberta et al. (eds.), Formulaic Language I-II. (Typological Studies in Language 82-83). Amsterdam: John Benjamins Publishing, I, 27-51. 